\title{
Reproductive biology and early establishment of Pinus elliottii var. elliottii in Brazilian sandy coastal plain vegetation: implications for biological invasion
}

\author{
Fernando Campanhã Bechara ${ }^{1 *}$, Ademir Reis², Kurt Bourscheid², Neide Koehntopp Vieira², Bruna Elisa Trentin ${ }^{1}$
}

'UTFPR/Coordenação de Engenharia Florestal, C.P. 157 - 85660-000 - Dois Vizinhos, PR - Brasil. 2UFSC/CCB - Departamento de Botânica, C.P. 476 - 88010-970 - Florianópolis, SC - Brasil.

*Corresponding author <bechara@utfpr.edu.br>

Edited by: Daniel Scherer de Moura

Received December 01, 2011

Accepted August 08, 2012

\begin{abstract}
Pinus is the most invasive woody taxon, exceeded only by herbaceous plants. This study reports the reproductive biology and early establishment of Pinus elliottii Engelm. var. elliottii, describing its invasive properties in a protected natural area of the Brazilian coastal sandy plains. We evaluated the seed germination and rain, longevity of seed viability and the initial dynamics of the seedlings of Pinus elliottii var elliottii through field and laboratory experiments. We recorded a continuous seed rain of about 204.0 viable seeds $\mathrm{m}^{-2}$ per year, with a $90 \%$ germination rate. The seeds exhibited a low longevity of viability in the soil and a dense, permanent seedling bank that may explain the high levels of pine invasion. The environmental impact caused by the pine's biological invasion suggests the recommendation for its immediate eradication, together with a restoration plan to restitute the native biodiversity gradually. Keywords: slash pine, germination, seed bank, seed rain, seedling dynamics
\end{abstract}

\section{Introduction}

The Pinus L. genus is found naturally only in the Northern Hemisphere throughout North America, Europe and Asia (Mirov, 1967; USDA, 1974), locations where originally it occupied harsh sites, such as extremely cold and arid regions, mountain tops and flat, acidic and low-fertility soils (Richardson and Bond, 1991; Richardson et al., 1994; Richardson and Higgins, 1998; Richardson, 2006). Pinus is the most invasive woody taxon, exceeded only by herbaceous plants (Pysek, 1998; Richardson and Rejmanek, 2004). Natural ecosystems invaded by pine occur in open phytophysiognomies or marginal habitats, such as grasslands, the vegetation of coastal sandy plains, dunes, scrubs, steppes, hilltops, savannas and lithological environments or disturbed areas in the pioneer stages of succession (Richardson and Bond, 1991; Richardson and Higgins, 1998; Zalba and Villamil, 2002). The 21 invasive Pinus species (Petit et al., 2004; Richardson and Rejmanek, 2004; Richardson, 2006), especially those of the sub-genus Diploxylon (Rejmanek and Richardson, 1996), are well documented to have high invasiveness in both the Northern (Richardson and Bond, 1991; Sturgess and Atkinson, 1993; Richardson and Higgins, 1998; Richardson and Rejmanek, 2004; Catling and Carbyn, 2005) and, particularly, Southern Hemisphere (Chilvers and Burdon, 1983; Corbett, 1991; Richardson et al., 1992; Richardson et al., 1994; Rejmanek and Richardson, 1996; Richardson and Higgins, 1998; Richardson and Rejmanek, 2004; Williams and Wardle, 2005; Richardson et al., 2008; Langdon et al., 2010; Simberloff et al., 2010). Richardson and Higgins (1998) verified the regular dispersion of Pinus seeds up to $8 \mathrm{~km}$ from its matrices and, occasionally, a more distant dispersal up to $25 \mathrm{~km}$.

In Brazil, Pinus elliottii Engelm. (slash pine; natural from Florida to South Carolina, United States (Mirov, 1967) I is one of the most invasive and aggressive exotic plant species. The first investigated Brazilian forestry stand of this exotic pine was introduced in the 1950s in the southern region of the country, demonstrating excellent development. Although this pine species causes enormous economic and ecological damage in Brazil, processes and traits that contribute to its invasive ability were rarely studied (Ziller and Galvão, 2003; Zanchetta and Diniz, 2006; Bechara and Reis, 2009; Almeida et al., 2010; Bourscheid and Reis, 2010; Falleiros et al., 2011).

The reproductive biology and the early establishment of Pinus elliottii Engelm var. elliottii were reported, and its invasive properties were described in a protected natural area of the Brazilian coastal sandy plains. To test these aims we studied the seed germination potential, seed rain, longevity of seed viability in the soil and seedling bank, all considered essential traits to understand the biological invasion dynamics of $P$. elliottii.

\section{Materials and Methods}

Study area - The study area was located in Florianópolis, state of Santa Catarina, Brazil $\left(27^{\circ} 27^{\prime}-27^{\circ} 35^{\prime} \mathrm{S}\right.$ and $\left.48^{\circ} 18^{\prime}-48^{\circ} 30^{\prime} \mathrm{W}\right)$. The climate in this area is of the moist subtropical type (Cfa), with an annual relative humidity of $80-85 \%$. The annual average temperature is $20^{\circ} \mathrm{C}$, with monthly averages oscillating between 24 ${ }^{\circ} \mathrm{C}$ (Jan.) and $15{ }^{\circ} \mathrm{C}$ (Jul.) and an absolute minimum temperature of $-0.9{ }^{\circ} \mathrm{C}$. The annual average rainfall is $1,400 \mathrm{~mm}$, with the rains distributed uniformly throughout the year.

In 1.962, the government of Santa Catarina State created the Rio Vermelho State Park, which encompassed an area of 1,400 ha. At that time, Berenhauser (1972) tested 25 species of pine growing on the dunes and restingas (vegetation of the Brazilian coastal sandy plains). The area comprises a mosaic of plant communities that occupy the sand plains formed by marine deposits during the late Quaternary, located between the sea and the 
Atlantic Forest mountain chain (Lacerda et al., 1993; Scarano, 2002). Five hundred hectares of experimental Pinus spp. plantations were established in the park in areas that included dunes, open shrub and forest restingas. After 40 years, approximately 250 ha of dunes and restingas adjacent to the plantations had been progressively invaded by P.elliottii var. elliottii, currently totaling approximately 750 ha of different levels of invasion.

Originally, the studied area consisted of forest restinga in which plantations of $P$. elliottii var. elliottii were planted ( $3 \times 4 \mathrm{~m}$ spacing) in 1963 . In 2003, the pine stands were 40 years old, with an average height and basal area of $20 \mathrm{~m}$ and $33 \mathrm{~m}^{2} \mathrm{ha}^{-1}$, respectively (Bechara and Reis, 2009).

Germination test - P. elliottii var. elliottii seeds were collected from dispersed cones in the litter of the adult pine stands of the experimental area. Seeds were processed and selected using the fluctuation method (USDA, 1974). The seeds were stratified in a moist cold $\left(3-5{ }^{\circ} \mathrm{C}\right)$ chamber for 0 (control treatment), 7, 15 and 30 days, representing treatments T0, T1, T2 and T3, respectively. The seeds were then placed in a seedling shed to germinate, in four blocks with one replication of the treatment in each block. Replications of 50 seeds were distributed in completely randomized blocks. The emergence of the seedlings (presenting cotyledons) in each treatment was quantified and statistically compared using an ANOVA - F test.

Seed rain - Twenty-seven permanent $1 \mathrm{~m}^{2}$ seed rain traps (wooden frames placed one meter above the ground, with a U-shaped greenhouse shade cloth bag) were distributed at adult $P$. elliottii var. elliottii stands of the experimental area. The traps were distributed every $15 \mathrm{~m}$, in three lines at a distance of $50 \mathrm{~m}$ from each other, in the center of the stands, at the boundaries and $30 \mathrm{~m}$ beyond the boundary, with nine traps comprising each line. The cones were randomly collected from different trees. The captured pine seeds were quantified monthly during one year, considering as viable seeds only those that presented cotyledons during the germination test.

Seed viability longevity - The longevity of seed viability was tested in a 1 ha-area in which a $P$. elliottii var. elliottii stand was harvested using minimal impact techniques, remaining some native trees. The experimental area was surrounded by adult $P$. elliottii var. elliottii stands, and its understory before the pine harvest presented minimal levels of invasion, being populated by 19 native woody species in a basal area of $13 \mathrm{~m}^{2} \mathrm{ha}^{-1}$ (Bechara and Reis, 2009).

Viable seeds, originating from five adult individuals of $P$. elliottii var. elliottii, were selected using the fluctuation method (USDA, 1974). A set of 100 seeds was protected by greenhouse shade cloth container $(16 \times 8 \mathrm{~cm})$. The containers were buried in the soil at a depth of 3 $\mathrm{cm}$ in a recently harvested $P$. elliottii var. elliottii stand for $90,180,270$ and 360 days (the dependent variable is the duration in the soil), constituting treatments distributed $25 \mathrm{~m}$ from each other in four blocks, with one replication of the treatment in each randomized complete block.

After these periods of storage in the soil, the seeds were tested for germination in the seedling shed, considering the seeds that presented cotyledons as viable. The treatments were quantified and compared using ANOVA (F-test) after data transformation $[\log (x+1)]$, since data showed no homoscedasticity of variances. Note that this method estimates the maintenance of the viability of the seeds and not the natural seed bank because the seed containers may exclude the effects of seed predators, the changes in the microenvironment, and the infection (Vazquez-Yanes and Smith, 1982; Garwood, 1989).

Seedling dynamics - The seedling dynamics of the seed bank naturally stored in the soil was evaluated at the same site used for testing the longevity of seed viability; the experimental area was surrounded by adult pine plantations. At a recently harvested 1 ha pine site inside the experimental area, one round plot of a $1 \mathrm{~m}$ radius $\left(3.1 \mathrm{~m}^{2}\right)$ was established every $10 \mathrm{~m}$, for a total of 100 plots (total sampled area of $314 \mathrm{~m}^{2}$ ) distributed in a regular grid over the hectare.

The $P$. elliottii var. elliottii seedlings (plants with cotyledons or true leaf development) inside each plot were counted and marked with aluminum tags in four assessments (totaling 1.5 year of monitoring), constituting different durations after the pine harvest: 1 year (Aug., 2003); 1.5 year (Feb., 2004); 2 years (Aug., 2004) and 2.5 years (Feb., 2005). The rate of mortality was then calculated. Additionally, the same harvested onehectare site was divided into five concentric zones, at 10 to $50 \mathrm{~m}$ beyond the plantation boundary. On each of the four evaluation dates, the new regenerating individuals were counted, excluding the individuals of the previous sampling. Each zone was considered an experimental treatment, and each of the four sampling times was considered a replication. Thus, the average density of the seedlings within the zones at the times was considered as the dependent variable and was compared using ANOVA (F-test).

\section{Results}

Germination test - No differences were observed for the time of germination $(\mathrm{F}=1.48, p>0.05)$. After 140 days, the seedling emergence was $90.0 \%, 89.0 \%, 89.0$ $\%$ and $86.5 \%$ for the T0 (seeds not stratified at $3-5{ }^{\circ} \mathrm{C}$ ), $\mathrm{T} 1$ (seeds stratified at $3-5^{\circ} \mathrm{C}$ for 7 days), T2 (seeds stratified at $3-5{ }^{\circ} \mathrm{C}$ for 15 days) and T3 (seeds stratified at 3-5 ${ }^{\circ} \mathrm{C}$ for 30 days) treatments, respectively (Figure 1 ).

Seed rain - P. elliottii var. elliottii demonstrated a continuous seed rain, dispersing approximately 204.0 viable seeds $\mathrm{m}^{-2}$ per year, with an explosive peak in Apr. (Figure 2). In this month, a mean of approximately 101 viable seeds $\mathrm{m}^{-2}$ were dispersed. 
Seed viability longevity - We found differences for the seedling emergence rate $(\mathrm{F}=7.56, p<0.05)$. Specifically, there was a difference between the seedling emergence rate for the seeds buried in the soil for 90 days and the other treatments. Moreover, there was an abrupt decline in the germination capacity, culminating in no germination after one year (Figure 3).

Seedling dynamics - One year after the harvesting of the adult pine stand, a mean density of 2 plants $\mathrm{m}^{-2}( \pm$ 2.81) and no dead seedlings were recorded (Figure 4). One year later, the population density reached its peak, with a mean of 20 plants $\mathrm{m}^{-2}( \pm 31.44)$. In response to the population boom, a highest mortality rate was observed six months later (during the second year). The accumulated population density observed 2.5 years after the harvesting of the adult pine stand indicates that the total new seedlings reached a density of 27 plants $\mathrm{m}^{-2}$ but the mortality rate was as high as $70 \%$.

The zones located $10 \mathrm{~m}$ beyond the pine plantation boundary revealed a greater population density than the other zones situated up to $50 \mathrm{~m}(\mathrm{~F}=5.20, p<0.001)$. Taking into account the mean population density for

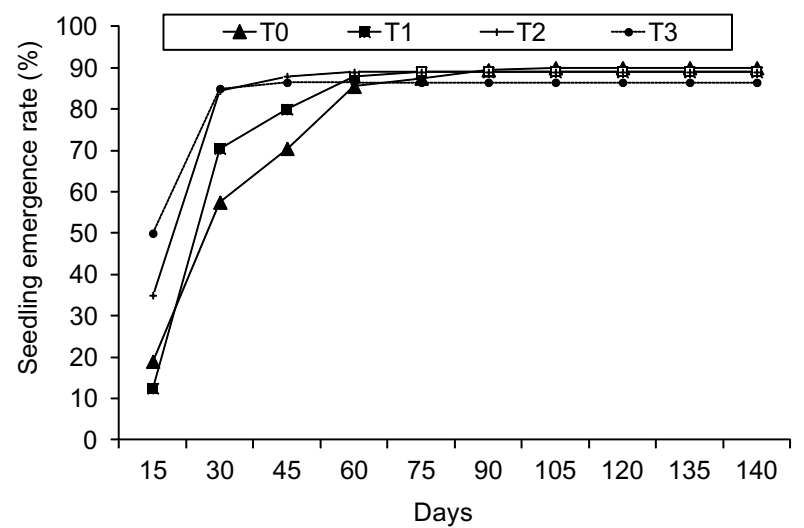

Figure 1 - Accumulated Pinus elliottii Engelm. var. elliottii seedling emergence rate. There were no differences between the treatments ( $p$ > 0.05). T0: control-treatment; T1: 7 days in moist cold; T2: 15 days in moist cold; T3: 30 days in moist cold.

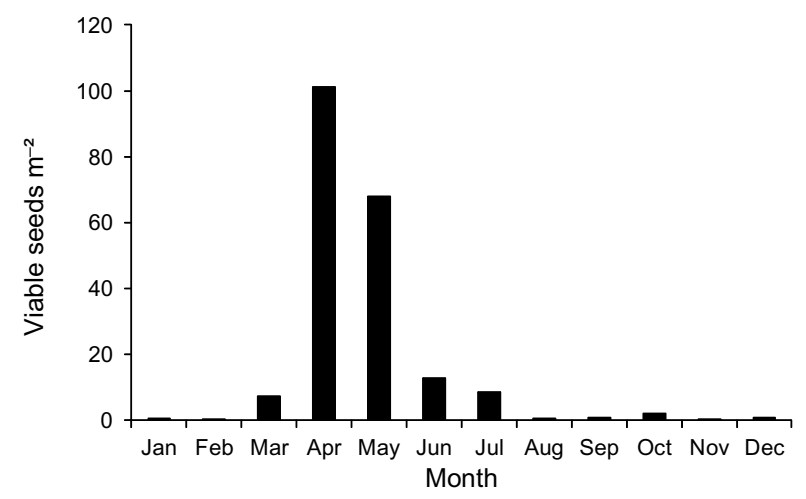

Figure 2 - Pinus elliottii Engelm. var. elliottii viable seed rain in Rio Vermelho State Park, SC, Brazil. each zone, we noted a decreasing exponential scale that progressed from a mean of 14 pine seedlings $\mathrm{m}^{-2}$ in the zone located close to the pine plantation boundary to 1 pine seedling $\mathrm{m}^{-2}$ in the farthest zone (Figure 5).

\section{Discussion}

A continuous seed rain (dispersing seeds with a high germination rate and low viability longevity in the soil) and a dense permanent seedling bank were observed, and it that may explain the high levels of pine invasion in the study area. The characteristics of pine species that are successful invaders, such as $P$. elliottii, include anemophily and anemochory, a high germination and productivity of the small seeds, a short chilling period required to overcome dormancy, a high seedling growth rate and short generation times (seven-year seed dispersal age with a three-year interval versus large-seed crops) (USDA, 1974; Richardson, 1996; Grotkopp et al., 2002; Richardson and Rejmanek, 2004).

Dormancy is a common factor in Pinus elliottii var. elliottii seeds (Mirov, 1967; USDA, 1974). The absence of seed dormancy found in the present study, with a high

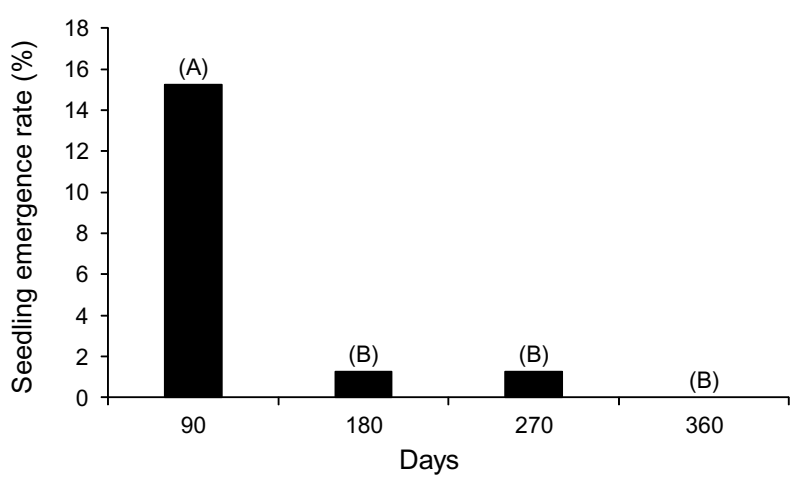

Figure 3 - Pinus elliottii Engelm. var. elliottii seedling emergence mean rate after burial for 360 days. Different letters indicate differences $(p<0.05)$.

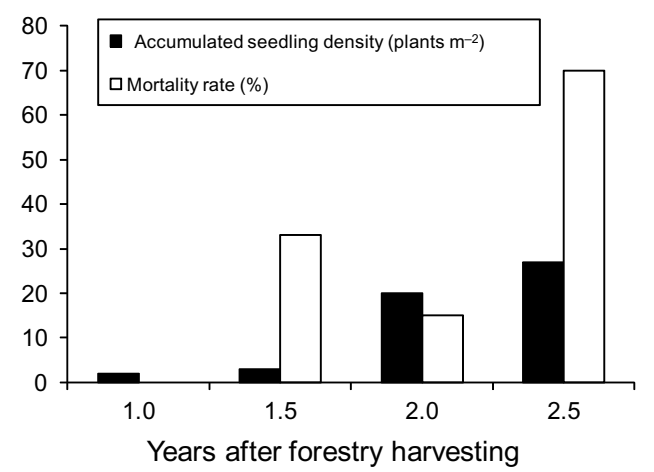

Figure 4 - Pinus elliottii Engelm. var. elliottii seedling density in restinga soil after the harvesting of the adult pine stand. 


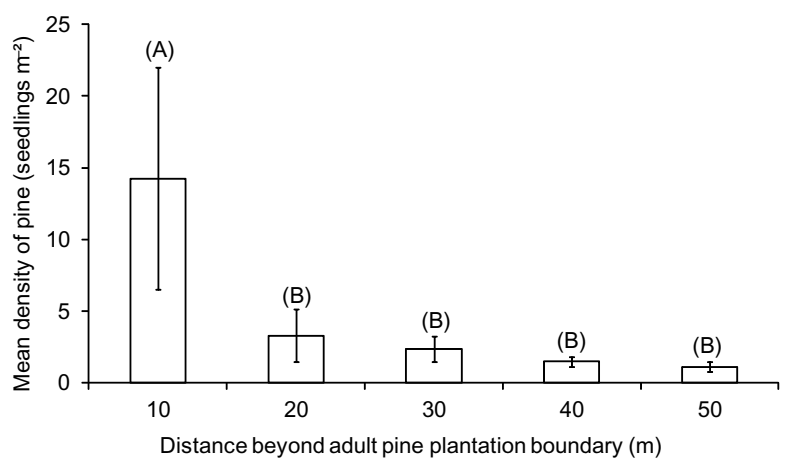

Figure 5 - Pinus elliottii Engelm. var. elliottii seedling dynamics in a restinga soil surrounded by adult pine plantations. Different letters indicate differences $(p<0.001)$.

percentage of germination (approximately $90 \%$ ) and no chilling period requirement to overcome seedling emergence, may explain the occurrence of the high levels of regeneration of slash pine in the studied area. To reduce the levels of invasion, it would be advisable for commercial reforestations of $P$. elliottii var. elliottii to consist of seeds from sources with higher levels of dormancy, such as those originating from Northern South Carolina (United States). There is also some potential for using transgenic techniques to reduce invasiveness, e.g., by inducing reproductive sterility (Richardson and Petit, 2006).

Propagule pressure is well known to be a factor in biological invasion. Therefore, the great abundance of $P$. elliottii seed rain may increase the chances of establishment, persistence, naturalization and invasion (Rouget and Richardson, 2003). Considering a $3 \times 4 \mathrm{~m}$ stand, we estimated that a single $P$. elliottii tree $(30-40$ years old) in this region may disperse 2,500 viable seeds $\mathrm{ha}^{-1}$ per year. A single reproductive $P$. elliottii individual may become the source of invasion (Richardson and Bond, 1991; Rouget et al., 2004). Moreover, Nuñez and Medley (2011) emphasizing that other factors, such as biotic resistance, may determine the observed pattern of invasion.

Pines have a soil seed bank that is virtually unknown (Tomback et al., 2001). P. elliottii var. elliottii presented viable seeds when stored for only 90 days in the restinga soil (Figure 3), suggesting the classification of a transient seed bank species (sensu Garwood, 1989). However, further studies about seed bank should address this question. The formation of a permanent seed bank is a survival strategy (Garwood, 1989; Keddy et al., 1989), and, when it is present in invasive species, their management becomes more difficult. Hence, the rapid loss of germination capacity observed in our study is probably a positive factor for the control of $P$. elliottii var. elliottii in protected areas.

The low longevity of seed viability and high germination percentage support the hypothesis that an increase in the population density is related to an increase in the seed rain. The rapid germination results in a $P$. elliottii var. elliottii grass-like seedling stage (USDA, 1974). The verified continuous seed rain feeds the formation of a $P$. elliottii seedling bank, particularly within the first $10 \mathrm{~m}$ beyond the plantation boundaries. This zone is extremely vulnerable to pine invasion and should receive the appropriate attention to prevent the spread of this species.

The initial stages of invasion are usually constrained by the availability of propagules. A high propagule pressure may, in some instances, be a better predictor of alien plant cover than any set of environmental factors (Rouget and Richardson, 2003; Richardson, 2006). Therefore, dunes and restingas may have a homogenous dispersal model (as determined by the propagule pressure) in which the proximity of the invasion focal point increases the biological invasion of pine (Rouget and Richardson, 2003).

\section{Conclusion}

Pinus elliottii var. elliottii may be an aggressive and invasive species that may alter subtropical restinga environments. Specifically, high levels of $P$. elliottii var. elliottii invasion were observed through a continuous seed rain. The low seed viability longevity in the soil and the dense seedling bank lead to a reduction in the empty spaces necessary for the occurrence of natural colonization by native species. The environmental impact caused by the biological invasion of pine at Rio Vermelho State Park suggests the need of its immediate eradication through a two-year program that control re-infestation, including the cutting of isolated, reproducing trees (generally five years of age in Brazil) and removing of cone litter in conjunction with a restoration plan.

\section{Acknowledgements}

To CAPES (Brazil), for master's grants, to the WWF-Ford Foundation and to Fundação O Boticário de Proteção à Natureza (Brazil), for financial support, and to Rosangela Aparecida Botinha Assumpção (UTFPR), for assistance in the statistical analyses.

\section{References}

Almeida, R.S.; Cielo-Filho, R.; Souza, S.C.P.M.; Aguiar, O.T.; Pastore, J.A.; Baitello, J.B.; Kanashiro, M.M.; Mattos, I.F.A.; Franco, G.A.D.C; Lima, C.R. 2010. Woody wet grassland: Cerrado physiognomy threatened by the contamination of Pinus elliottii Engelm in the Itapeva Ecological Station, São Paulo State. Revista do Instituto Florestal 22: 71-91 (in Portuguese, with abstract in English).

Bechara, F.C.; Reis, A. 2009. Demonstrative unit of ecological restoration on an arboreal restinga contaminated by Pinus in the Rio Vermelho State Park. p. 153-163. In: Tres, D.R.; Reis, A., eds. Systemic perspectives for the conservation and restoration: the point to the context. Barbosa Rodrigues Herbarium, Itajai, SC, Brazil (in Portuguese, with abstract in English). 
Bourscheid, K.; Reis, A. 2010. Invasion dynamics of Pinus elliottii Engelm. on restinga under a restoration process inside Rio Vermelho State Park, Florianópolis, SC. Biotemas 23: 23-30 (in Portuguese, with abstract in English).

Berenhauser, H. 1972. Afforestation of coastal swamps and dunes at Rio Vermelho. Floresta 4: 13-17.

Catling, P.M.; Carbyn, S. 2005. Invasive scots pine, Pinus sylvestris, replacing corema, Corema conradii, heathland in the Annapolis valley, Nova Scotia. Canadian Field-Naturalist 119: 237-244.

Chilvers, G.A.; Burdon, J.J. 1983. Further studies on a native Australian eucalypt forest invaded by exotic pines. Oecologia 59: 239-245.

Corbett, D.P. 1991. Control of cluster pine on French Island, Victoria. Plant Protection Quarterly 6: 128-129.

Falleiros, R.M.; Zenni, R.D.; Ziller, S.R. 2011. Invasion and management of Pinus taeda in altitude grasslands of Paraná Peak State Park, Paraná, Brazil. Floresta 41: 123-134 (in Portuguese, with abstract in English).

Garwood, N.C. 1989. Tropical soil seed banks: a review. p. 149209. In: Leck, M.A.; Parker, T.V.; Simpson, R.L., eds. Ecology of soil seed banks. Academic Press, New York, NY, USA.

Grotkopp, E.; Rejmanek, M.; Rost, T.L. 2002. Toward a causal explanation of plant invasiveness: seedling growth and lifehistory strategies of 29 pine (Pinus) species. The American Naturalist 159: 396-419.

Keddy, P.A.; Wisheu, I.C.; Shipley, B.; Gaudet, C. 1989. Seed banks and vegetation management for conservation: toward predictive community ecology. p. 347-363. In: Leck, M.A.; Parker, V.T.; Simpson, R.L., eds. Ecology of soil seed banks. Academic Press, New York, NY, USA.

Lacerda, L.D.; Araújo, D.S.D.; Maciel, N.C. 1993. Dry coastal ecosystems of the tropical Brazilian coast. p. 477-493. In: van der Maarel, E., ed. Dry coastal ecosystems: Africa, America, Asia and Oceania. Elsevier, Amsterdam, Netherlands.

Langdon, B.; Pauchard, A.; Aguayo, M. 2010. Pinus contorta invasion in the Chilean Patagonia: local patterns in a global context. Biological Invasions 12: 3961-3971. Mirov, N.T. 1967. The Genus Pinus. Ronald Press, New York, NY, USA.

Nuñez, M.A.; Medley, K.A. 2011. Pine invasions: climate predicts invasion success; something else predicts failure. Diversity and Distributions 17: 703-713.Petit, R.J.; Bialozyt, R.; Garnier-gere, P.; Hampe, A. 2004. Ecology and genetics of tree invasions: from recent introductions to quaternary migrations. Forest Ecology and Management 197: 117-137.

Pysek, P. 1998. Is there a taxonomic pattern to plant invasions? Oikos 82: 282-294.

Rejmanek, M.; Richardson, D.M. 1996. What attributes make some plant species more invasive? Ecology 77: 1655-1661.

Richardson, D.M. 2006. Pinus: a model group for unlocking the secrets of alien plant invasions? Preslia 78: 375-388.

Richardson, D.M.; Bond, W.J. 1991. Determinants of plant distribution: evidence from pine invasions. The American Naturalist 137: 639-668.

Richardson, D.M.; Higgins, S.I. 1998. Pines as invaders in the southern hemisphere. p. 450-473. In: Richardson, D.M., ed. Ecology and biogeography of Pinus. Cambridge University Press, Cambridge, MA, USA.

Richardson, D.M.; Petit, R. 2006. Pines as invasive aliens: outlook on transgenic conifers in the Southern Hemisphere. p. 169188. In: Williams, C., ed. Landscapes, genomics and transgenic conifer forests. Springer, Dordrecht, Netherlands.

Richardson, D.M.; Rejmanek, M. 2004. Conifers as invasive aliens: a global survey and predictive framework. Diversity and Distributions 10: 321-331.

Richardson, D.M.; MacDonald, I.A.W.; Holmes, P.M.; Cowling, R.M. 1992. The ecology of fynbos: nutrients, fire and diversity. Oxford University Press, Cape Town, South Africa.

Richardson, D.M.; van Wilgen, B.W.; Nuñez, M.A. 2008. Alien conifer invasions in South America: short fuse burning? Biological Invasions 10: 573-577.

Richardson, D.M.; Williams, P.A.; Hobbs, R.J. 1994. Pine invasions in the Southern hemisphere: determinants of spread and invasibility. Journal of Biogeography 21: 511-527.

Rouget, M.; Richardson, D.M. 2003. Inferring process from pattern in plant invasion: a semimechanistic model incorporating propagule pressure and environmental factors. The American Naturalist 162: 713-724.

Rouget, M.; Richardson, D.M.; Milton, S.J.; Polakow, D. 2004. Predicting invasion dynamics of four alien Pinus species in a highly fragmented semi-arid shrubland in South Africa. Plant Ecology 152: 79-92.

Scarano, F.R. 2002. Structure, function and floristic relationships of plant communities in stressful habitats marginal to the Brazilian Atlantic rain forest. Annals of Botany 90: 517-524.

Simberloff, D.; Nuñez, M.A.; Ledgard, N.J.; Pauchard, A.; Richardson, D.M.; Sarasola, M.; Van Wilgen, B.W.; Zalba, S.M.; Zenni, R.D.; Bustamante, R.; Peña, E.; Ziller, S.R. 2010. Spread and impact of introduced conifers in South America: lessons from other southern hemisphere regions. Austral Ecology 35: 489-504.

Sturgess, P.; Atkinson, D. 1993. The clear-felling of sanddune plantations: soil and vegetational processes in habitat restoration. Biological Conservation 66: 171-183. Tomback, D.F.; Anderies, A.J.; Carsey, A.S.; Powell, M.L.; MellmannBrown, S. 2001. Delayed seed germination in whitebark pine and regeneration patterns following the Yellowstone fires. Ecology 82: 2587-2600.

United States Department of Agriculture [USDA]. 1974. Seeds of Woody Plants in the United States USDA, Washington DC, USA. (Agriculture Handbook, 450).

Vazquez-Yanes, C.; Smith, H. 1982. Phytochrome control of seed germination in the tropical rain forest pioneer trees Cecropia obtusifolia and Piper auritum and its ecological significance. New Phytologist 92: 477-485.

Williams, M.C.; Wardle, G.M. 2005. The invasion of two native Eucalypt forests by Pinus radiata in the Blue Mountains, New South Wales, Australia. Biological Conservation 125: 55-64.

Zalba, S.M.; Villamil, C.B. 2002. Woody plant invasion in relictual grasslands. Biological Invasions 4: 55-72.

Zanchetta, D.; Diniz, F.V. 2006. Study of biological contamination by Pinus spp. in three different areas in the Ecological Station of Itirapina (SP, Brazil). Instituto Florestal 18: 1-14 (in Portuguese, with abstract in English).

Ziller, S.R.; Galvão, F. 2003. Environmental degradation of a grassland ecosystem in Parana state with biological invasions of Pinus elliotti and P. taeda. Floresta 32: 41-47 (in Portuguese, with abstract in English). 